
SB 476

. W3

Copy 2

Landscape Engineering in the National Forests

\author{
By \\ FRANK A. WAUGH \\ Collaborator
}

\title{
1918
}




$$
\begin{aligned}
& \text { SB476 } \\
& \text { W3 } \\
& \text { copyz }
\end{aligned}
$$

ก. of D. SEP $16 \quad 1918$ 


\section{Landscape Engineering in the National Forests}

7 HE school-book definition of landscape gardening (practically

1 synonymous with landscape architecture or landscape engineering) recites that this is "the art of improving land for human use and enjoyment in such a manner as to secure the maximum utility combined with the maximum of beauty." It is an error to regard the subject as concerned mainly with planting trees and shrubs or to imagine its main function to be the supply of some "ornamental" (always superficial) disguise for some unsightly utility. On the contrary, it must be recognized as a principle fundamental to all art, and to life, that no utility should need disguise, and that every kind of artistic treatment, instead of being superficial, must be organic-structural.

Translated into the practical terms of daily life in the National Forests, this means that landscape engineering will recognize the primary utilities, not as a necessary evil, but as necessarily good. Instead of these utilities standing in the way of the objects which the landscape engineer wishes to accomplish, they become a most acceptable part of his own undertaking.

Obviously, once this point of view is accepted the landscape engineer and the practical forester are working for precisely the same thing. Far from being at cross purposes, each trying to 
bring to pass things which conflict with the objects pursued by the other, they are partners in a common enterprise-the harmonized, rational development of the National Forests to their maximum usefulness, which includes both the use of material resources for the supply of economic needs and the enjoyment of esthetic advantages.

The foresters also have a schoolbook definition which is worth recalling. It recites that their profession is concerned with the art of handling forest lands in such a manner as to serve best the purposes of the owner. That purpose is sometimes money income; sometimes it is the production of material for some particular kind of use; or it may be embellishment of a pleasure park. Often several purposes are combined. It is doubtful, however, whether it would be possible to find anywhere on the earth's surface forests of any size where the "purposes of the owner" combine so many and so widely varying kinds of utility as are found in the case of the National Forests. Basic in the plans for managing them has been the conception that they should be made to yield every form of use that can be got out of them, and the maximum net total of use. Foresters could not, if they would, deny that the beauty of the landscape and public enjoyment of that beauty are matters which must come into their account. That there is no desire to deny it is sufficiently evidenced by the important place which the Forest Service is giving to the development of recreation resources. These it counts as deserving a place with timber, water, and forage. The forester and the landscape engineer, therefore, are at one 
in their fundamental point of view regarding these public properties-or perhaps it were better to say they make a team.

The landscape engineer must, under the terms of the definition of his art already given, include in any plans which he may formulate for the National Forests the utilities other than those involving the element of beauty which they possess. The forester likewise must include in his plans the element of beauty wherever its public value is manifest. In other words, both must have the same set of objectives. The first step in planning must be recognition of the full set, and, if the objectives can not all of them be fully realized because they conflict in part, a well-balanced decision must be sought as to their relative importance and the best method of reconciling them.

As a specialist, the landscape engineer will make his peculiar concern three closely related objectives (though always recognizing that they can not be pursued without constant consideration of the material utilities involved)-viz, (I) to preserve the native landscape in all its prestine beauty; (2) to make it physically accessible to the largest number of persons; (3) to present its beauties in the most logical, intelligible, and convincing manner.

It should be obvious that all these purposes are entirely compatible with the objectives which economic use of the material resources of the Forests sets up. The principal enemy of the landscape is fire, which is also the arch enemy of the forest regarded as a source of timber and water. One principal means of fire protection is found in opening a good system of trails, and this contributes directly to the landscape engineer's second 


\section{Landscape Engineering}

objective. A good many persons, considering the matter too narrowly, have concluded that lumbering operations, which are essential to the practice of forestry, are fatal to landscape beauty, and must therefore suffer the stern disapproval of the landscape engineer. As a general statement this is false and mischievous. There are many ways of adapting timber cutting to esthetic needs. The landscape engineer may himself employ cutting in order to bring out better natural beauty. While in particular instances esthetic considerations might impose an absolute veto on any interference with the natural conditions, no such universal rule should be laid down.

At the present time the National Forest areas offer some of the largest and most fascinating problems ever presented to the landscape-engineering profession, whether considered in their social aspects or in view of the technical problems involved. But any discussion of either of these broad social questions or of the fundamental technical considerations would be quite out of place here. For the present it is desired only to give some practical suggestions, from the point of view of the landscape engineer, for the management of problems which almost daily confront the supervisor or ranger in the field. These problems are mainly of three kinds, (I) the layout of special-use permit areas for summer colonies, (2) the location of trails where serious consideration is given to the beauty of surrounding scenery, and (3) the location and development of ranger stations. 


\section{Summer Camp Areas}

IN EVERY Forest Service district there now exists a considerable

1 demand for sites on which to build permanent summer camps. On certain Forests this demand is so eager as to outrun the supply. In a few cases the leasing and management of such areas has become the principal occupation of the local forest officers.

Unquestionably the National Forests include much delightful wild country particularly adapted to summer camping and to other forms of recreation, such as hunting and fishing, which naturally go with it. The Forest Service has definitely adopted the policy of developing such recreation utilities, and we should therefore carefully examine the technical questions involved with a view to meeting the practical problems in the most effective way.

The territory usually desired for permanent camps is treecovered, and lies in canyons, along mountain streams, or beside mountain lakes. It nearly always presents a decidedly uneven topography, insomuch that it is often a serious problem to find practicable sites on which to place the camp houses. The territory, moreover, is nearly always wild, lying at a considerable distance from any city or large town; and this wildness and remoteness are generally held to be fundamentally desirable qualities. 
Under existing conditions many forest supervisors and rangers find themselves confronted with the duty of subdividing such recreation tracts into lots suitable for the use of permittees. The Washington office has issued instructions covering the method of making and recording the necessary surveys, but back of the survey there lies a problem in landscape engineering which many of the field men have found puzzling in the extreme. The subjoined suggestions are offered with the hope of helping the men in the field to a clearer understanding of these landscape engineering problems and of the means whereby they may be solved.

Before discussing the subdivision plan it will be advantageous

Size of

Lots to clear the way by deciding upon the size of the lots to be assigned for these summer camps. At present there is a considerable diversity of practice and a noteworthy lack of standards in this matter. Some diversity of practice is certainly desirable, owing to the diversity of conditions, but it is desirable at the same time to have a clearer ideal (or standard) to which to work.

The standard of village life in the United States is approximately four residences to each acre (represented by lots Ioo by roo feet). Wherever detached residences are built-that is, everywhere except under crowded city conditions - the house lot 50 by 100 feet is regarded as the minimum. This gives us only eight lots to the acre, disregarding streets. If the street area is figured in, this maximum crowding will give only a fraction over six houses to each acre. It may be added that the rate of 16 families to the acre is admitted in modern city planning only for the extremer 


\section{in the National Forests}

forms of crowded industrial housing, employing two and four family residences.

To adopt upon the recreation areas of the National Forests a standard of lot subdivision corresponding to the lowest forms of factory housing is manifestly absurd. One of the most serious and fundamental purposes of recreation in the Forest is to escape from these very conditions - to get away from city crowding and to give to each person the feeling that for once he has room to expand. The entire psychological, social, and economic foundation for recreation lies here; and if this foundation is undermined we may fairly doubt the adivisability of building further.

In the judgment of the writer one acre ought to be regarded as the standard size for the summer-camp permit on the National Forests. This will be represented by a lot 200 by 200 feet, or I 50 by 267 feet.

This standard, however, should be freely departed from. A strict uniformity in the size or shape of lots should be regarded as particularly undesirable. The one acre standard, however, may be held as the ideal and may be approximated in a large number of cases.

Certain of the summer-camp areas are so restricted in size and the demand for camp space is so great that substantial concessions in size of lots may seem justified in order to accommodate a larger number of applicants. In some of these cases the mitigating circumstances are so urgent as to overcome all objections. It generally happens, furthermore, that the resulting lots are not completely surrounded by other little lots. More frequently they are open on one side to a river or lake; and per$49628^{\circ}-18-2$ 
haps also on the opposite sirle are open to the whole hinterland. The permittee is by no means confined to his one-half acre or onequarter acre, but has the free use of an unlimited area before and behind his leasehold.

Even under such conditions I would regard one-half acre as the minimum lot size; and this amount ought to be assigned to each permittee for his protection, even though his lot will include some land too rough for practical use. If we have under management a particularly popular line of lake shore, for example, it might be possible to build double the number of camps by halving the size of the lots; but if lots are reduced to 50 feet in width and occupied by shacks, the entire lake shore is made squalid, and the very attraction which first drew campers thither is destroyed. It is important to observe, too, that the crowding of campers inevitably tends to shabbier building.

In speaking of "shacks" we should regard the spirit rather than the letter. It would be perfectly simple to adopt a rule that no cottage costing less than $\$ 300$ or $\$ 500$ would be permitted. Such rules have been widely used ontsicle the Forest Service, and their operation is usually commended. Yet there are objections to the principle, especially in the case of the National Forests. What is desired is to prevent, by rigorous means if necessary, the building of disreputable, unsightly structures which disfigure the natural landscape surroundings. It is evident that a cheap $\log$ hut, properly placed, and neatly built, may be more in keeping . with its forest environment than would a $\$ 50,000$ Italian villa. This might be called a matter of taste; it is in fact merely a matter of common sense. No reasonable man need misunderstand. 


\section{in the National. Forests}

There is, however, a still deeper, greater, and commoner danger in the crowding of houses on small areas within the Forests. Anyone who observes actual developments, for example at lakeside resorts generally, will be struck with the obvious fact that a certain number of the "campers" are attracted by the social delights of the crowd much more than by the esthetic inspiration of the landscape or the opportunity for quiet communion with nature. It may be fair, however, ${ }^{+} \mathrm{o}$ assume that the Forests, with their concomitant lakes, streams, and mountains, should be offered primarily to persons who delight in the works of nature and in the beauties of the landscape, and that such persons should be protected against the crowding of others whose primary desire is to be in company.

Let us say, therefore, that I acre should be recognized as the standard size for camp-permit lots; that lots down to one-half acre, or even somewhat smaller, may be laid out where a special demand exists and where such lots will be open on at least one side, the opening being toward some lake, stream, or unoccupied land (frontage on street not counted); but that under no circumstances whatever should more than four houses be permitted on any one acre. These standards are not to be slavishly followed, but are to be regarded generally as minima.

It may be proper to suggest here that, in general, it would seem wise to proceed with some deliberation in the development of these areas, not assuming that every applicant for a permit must be accommodated forthwith. There are ample areas for camping on National Forests whenever they can be made accessible by trail, automobile road, stage, or railroad, and these transportation facilities will be gradually exterided in time. Instead of over- 
crowding areas now available it would seem better policy to seek to open new areas elsewhere.

A considerable proportion of the areas to be used for camps lies

General

Layout. in strips along streams or lake shores. The subdivision plan then necessarily presents a single row of lots. These may join one another, or there may be more or less frequent and more or less irregular open spaces between them. Such occasional breaks in the lot series are usually desirable as providing public rights of way hetween the stream and the back country.

Such rows of lots are rarely lain to a straight line, and probably should never be so surveyed. Where conditions pernit, the alignment will usually be parallel with the stream or lake shore. In rare instances the lot may extend quite to the shore; in most circunstances it will be better to retain the shore for a clistance of from 50 to 500 feet back for public use. 'The shores are thus reserver to the full control of the Forest Service, a matter of some consequence at times.

In rough topography the position of lots is sometimes deternined more by the character of the slope than hy the shore line. 'Thus, there may be comparatively level benches at a little distance back, and the superiority of these as building sites should be recognized by conforming the lots to the position of the canp houses. Always in the work of lot subdivision special care should be exercised to make sure that each lot includes a practicable building site. It is often worth while to indicate these sites on the layout maps.

A public service road or trail is usually necessary with such a linear lot subdirision. This road should, whenever possible, run at the rear of thic lots. 


\section{in the National Forests}

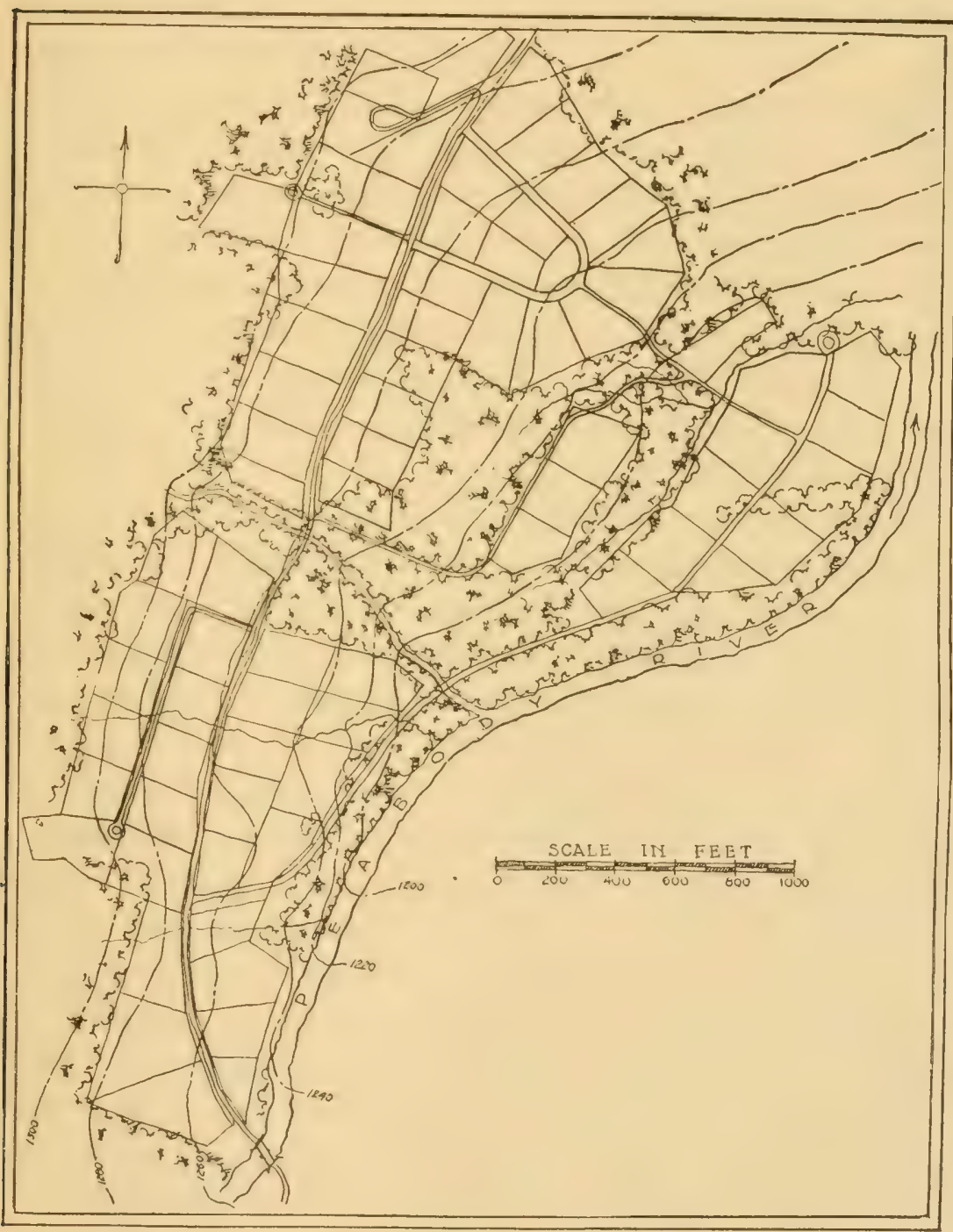

Frg, I, - White Mountain National Forest. Dolly Copp Farm subdivision. 
Where larger tracts of land have to be subdivided into build-

Larger

Layouts ing lots there is always a strong tendency to follow the "checkerboard system"- -that is, to make a rectangular plan. For the purposes in view on the recreation areas of the National Forests this is precisely the worst arrangement that can be made. First of all, it tends toward crowding, which is one of the things to be carefully avoided. What is more, the straight lines are stiff and unnatural, whereas we most of all wish to make these camp sites free, easy, natural, wild. The square layout is city-like, and we are trying to get away from the city.

Yet an irregular, naturalistic, informal layout is in practice exceedingly hard to secure. Simply to make a line crooked instead of straight does not make it natural. An irregular, layout, when unskillfully made, is about as ugly an affair as one could invent. It is certainly worse than a plain, honest checkerboard.

Some skill, some training, some artistic ability is required to get the best results in this field, but the following suggestions may make it possible to deal effecctively with the usual Forest Service cases. The work should generally be developed through four successive stages; reconnaissance, survey, design, and layout.

I. Reconnaissance.-The ground should be examined with reference to its general adaptability to the purposes in view. The conditions of accessibility, topography, water supply, drainage, timber cover, altitude, and scenery will determine whether this tract or some other will best meet the requirements. This 
preliminary inspection, moreover, will usually decide the location of main roads and other features.

2. Survey.-In all cases a topographic survey should be made. This should have somewhat the character of the more detailed land-classification surveys, but should be still more intensive. In general, the survey should record all topographic features, as springs, water courses, timber, brush, etc. Contours should be run at ro-foct intervals; or, in cases where careful work is desired, at 5 -foot intervals.

These surveys should nearly always be mapped at a scale of roo feet to the inch, or sometimes at 50 feet to the inch. The engineers' (decimal) scales should always be preferred for this work to the surveyors' scales in general use in the Forest Service.

The work of these surveys may be done with the special Abney, or with compass and hand level, though of course a transit will give much better results where it can be had. A plane table, properly used, is the best instrument of all.

It needs to be said here that the instruments and methods in general use in the Forest Service are not well suited to the work under discussion. In general, however, it will be necessary for the man on the ground to make the best use he can of the facilities at his command.

3. Design.-After the survey has been mapped on a conveniently large scale, the plan for the future layout should be carefully studied on this map. This study will proceed most smoothly if it follows a regular course. First, the important points should be located, such as entrance, features like ranger station, post 
office, store, hotel, or boat landing. Second, the principal roads connecting these points should be designed. Third, the secondary roads or trails should be determined. Last of all should follow the subdivision into lots. (When such areas develop without design the lots are often located first and the other steps taken backward.)

Probably the most critical step in this design is the location of the roads or main trails. The best way to secure satisfactory results is to follow the natural topography. The main roads will rise along watercourses and will cross over saddles. Where there is a steep slope they will follow the contours, rising or falling with varying grade within the grade linit (preferably a limit of 6 per cent). If skill and a good eye are combined on this problem the resulting road will fit naturally to the land, it will not appear stiff, forced, or artificial, and it will seldom be straight. Neither will it be offensively crooked, but rather gracefully modulated to the topography.

The width and character of the streets to be laid out along these lines will vary so greatly that no rules can be given. Stiff and formal city-wise treatment is to be avoided, however, and the wild forest character is to be preserved as far as possible.

In cutting up the remaining space into individual lots, considerable variety should be sought. Lots should be of varying sizes, shapes, and frontage, and should present different kinds of outlook and cover. Some campers want to live in the sun; others insist on keeping close under the trees. It is not obligatory in most cases that every inch of land be used. Open spaces between lots are sometimes desirable. 
In some of the larger enterprises now developing it is necessary to plan for important public reservations, such as public landing places on lake fronts, civic centers in village communities, public playgrounds, and almost always public camp grounds. These utilities are important, and there is danger of their being overlooked by the man who is not familiar with landscape engineering. But once their need is recognized, their disposition in the plan can best be left to the practical judgment of the man on the job.

+. Layout.-After the design has been carefully studied on paper, checked and criticized by as many persons as possible, this plan should be taken hack to the tract and laid out on the ground. Unless the prelininary surveys have heen very exhaustive it will be found that many trifling modifications of detail will be advisable. Slight shifts of roadways and small changes in lot lines can be made to adrantage. However, if serious alterations appear to be needed, this condition will indicate a defective survey, or an insufficient design, or both, and the only safe method will be to go back to the besinning and check the work over from the first.

One particular condition recurs so frequently in this field that

The Lake Problem

it may fairly be treated as a distinct type and called the "lake problem." When a summer camp begins to form about a lake it nearly always grows as a marginal ring. If the demand for camps continues after the first ring is completed, another ring is formed, until finally there may be several concentric rings closely resembling the growth rings on top of a sawed stump.

$49628^{\circ}-18-3$ 


\section{Landscape Engineering}

The result of such growth undirected is to place the roads or other traffic ways upon these concentric lines. Yet the movement of traffic (that is, of persons) is mainly radial, to and from

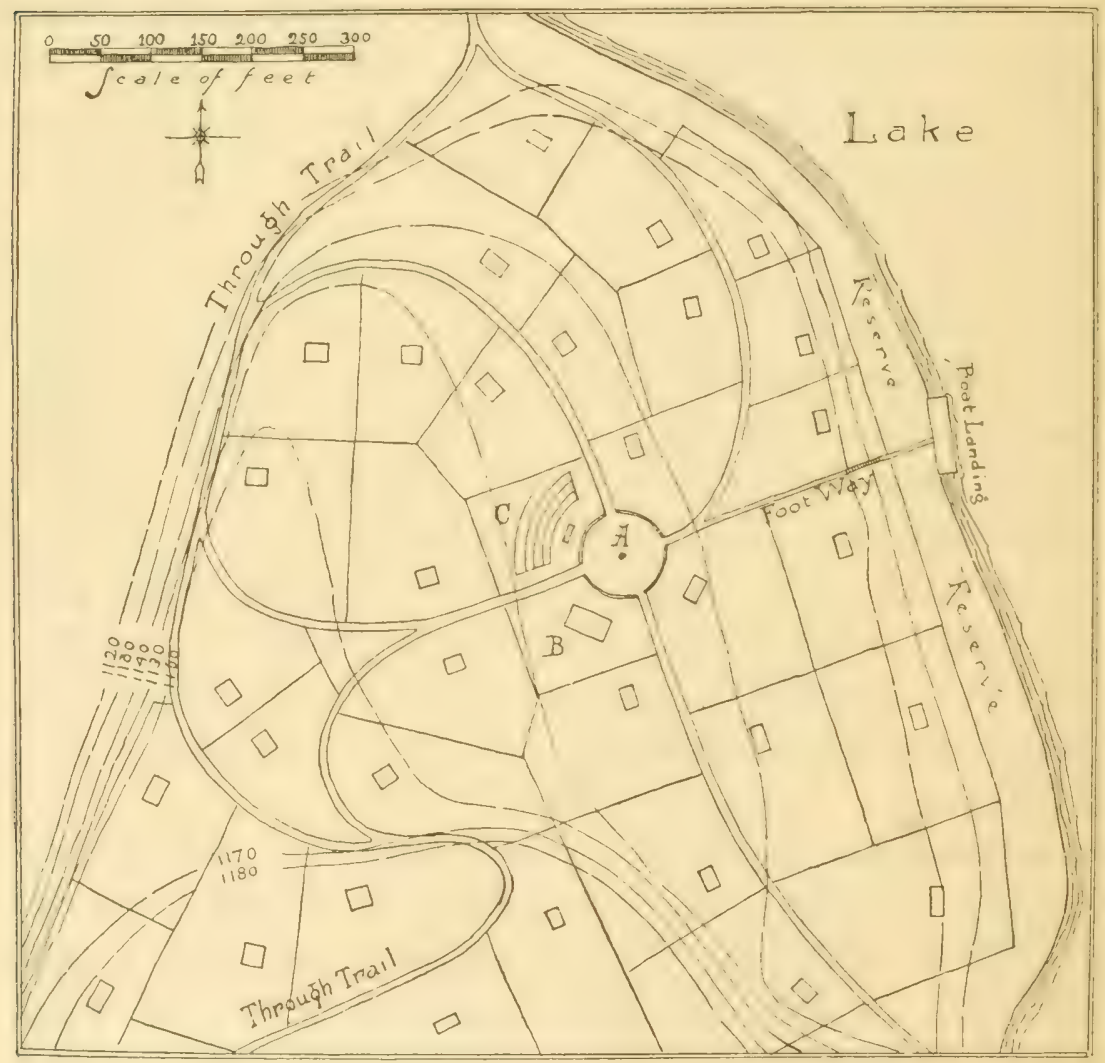

FIG. 2.-Summer camp colony-Informal layout.

the lake. It is plain, therefore, that the designer who is able to attack the "lake problem" in advance of settlement will, if possible, place his main roadways in radial directions. This is nearly 
always difficult, especially where the slopes are steep, but it is seldom impossible or impracticable. If the slope is too great to permit straight direct radial traffic lines, these paths may be bent and carried out along grades of 6 or 10 per cent. They will thus form volutes rather than radii, but the practical result is the same, while the curved lines will be more agreeable to the eve and even to the feet than though these paths stuck out like the spokes of a wheel.

It will be (lesirable further in all such layouts to break up the rigiclity of the concentric rings of lots as much as possible. This can be accomplished hy introducing lots of varying size and form.

ivery competent landscape engineer has in his equipment a whole "box of tricks" for breaking up the stiffness of a geometrical layout and of increasing the irregularities and informalities of his design. Of course it is necessary, to make this procedure successful, that the designer shall have a good eye for topography and that he shall form his irregularities of plan upon the natural lay of the land. ()therwise it is worse than any possible geometrical plan. 'The forest ranger can not fairly be asked to know these refinements of the landscape designer's art, but he may have the good eve for topography, and if he will give serious study to any particular piece of land he should be able to achieve a layout which will look more like a wild native tract of mountainside and less like a checkerboard.

Forest supervisors should be careful to anticipate the public demand in all summer-home colonies. It is much easier to secure a good layout and a convenient administration if the Forest Service can take the problem in hand before numerous permittees or 
squatters are already establisher. It is better arlministration to have three or four tracts survered and designed with no demand

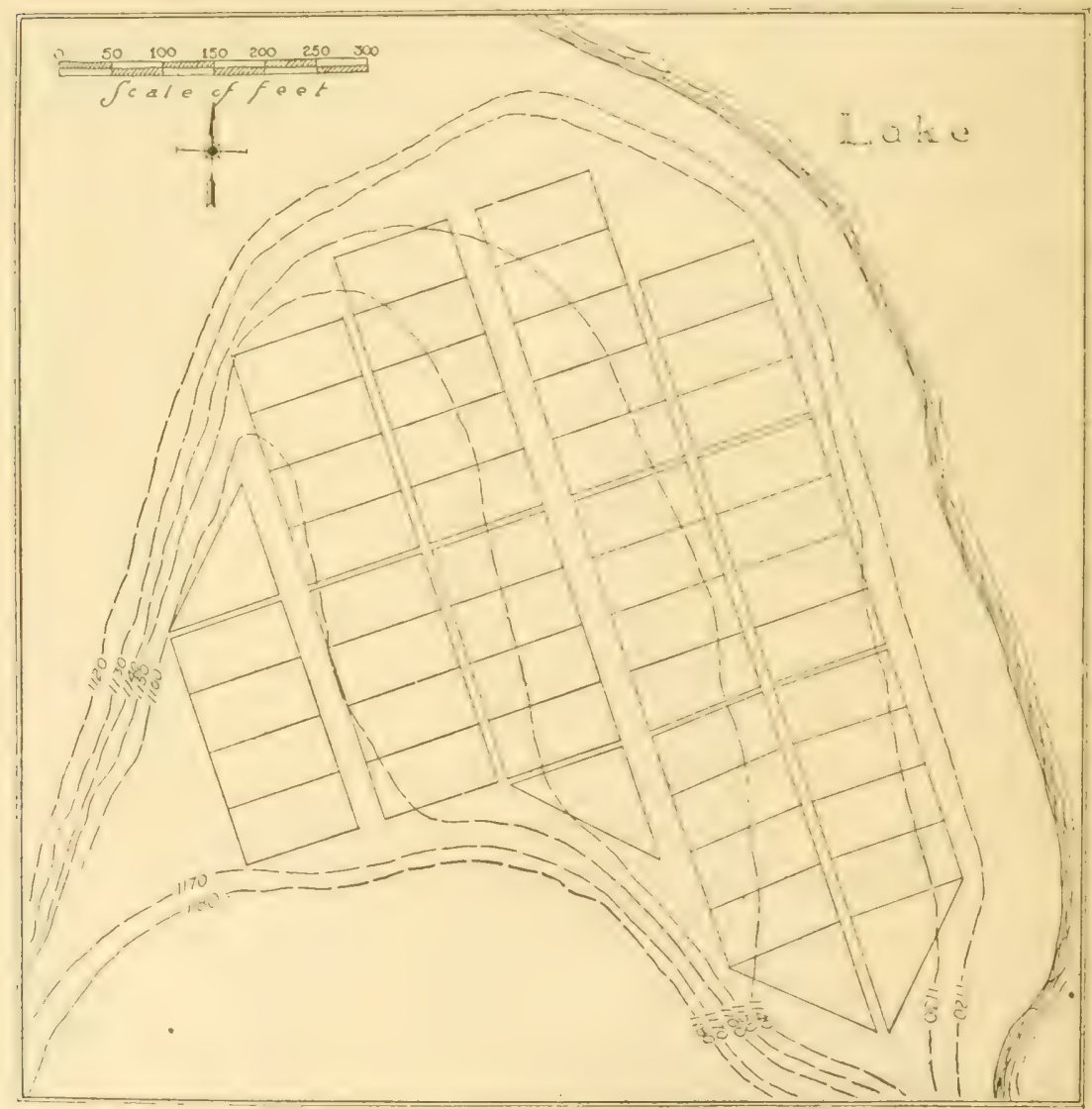

FIG. 3.-Summer-camp colony-" "Checkerboard" layout.

for leases than to have one colony established in helter-skelter fashion hefore the Forest Service gets started with its plans. 
There is always danger, too, that such a colony, once estal)lished, will be quite too seriously accepted by local officers. It is nearly always possible and altogether best to deal radically with such mistaken derelopments. There will be some immediate ruptures, and some temporary inconvenience, but in the long future evervody will be glad that some one had the courage to make a new and better beginning. 


\section{Trail Location with Reference to the Development of Scenery}

TN THE: National loorests are thomsands of miles of trails. 1 Many of these run through picturespue canyons, along leantiful streans, over ylorions monntain ranges, or through noble forests. On many of them the trateler meets the most delightful scenery. To this scenery the forest supervisors and rangers have always been responsive. Sone of the existing trails have heen located frankly with the intent of reaching good landscape features.

Since the problem of locating trails (or roads) with reference to the development of landseape is, howerer, a fundanental problem in landscape engineering, and inasmuch as the landscape engineer has worked ont certain technical methods for the solution of such problems, it will he worth while to consider the whole matter from this point of view.

It must be expecterl that in the majority of cases the location of fiorest Service trails will still be ruled by administrative expediency. They will be built where they are needed for practical utility, directed hy the shortest practical routes, laid 1 pon the easiest effective grades, and with due consideration for heapness of construction. The main object of a trail will still be to ret there. I $\cdot \mathrm{t}$ it will be possible, in many cases, without 
loss of administrative efficiency, to get more effective riews of the landscape atong the way; and anyone who knows the forest officer on his own territory and appreciates his love for the outdoor world, will readily expect him to make the most of the landscape in which he lives.

Moreover a certain number of trails will he built where landscape development is the paramount ol)ject in view. In such cases, the methods of the landscape engineer may fairly be given precedence.

Somewhat roughly stated, the method used by the landscape

General

Method enrineer in the location of roads, trails, or paths is as follows: The principal points of interest (such as outsicle views, vistas up or down a stream, waterfalls, particularly good trees, etc.) are sought out first of all. The route is then laid in such a manner as to connect these points, having due regard to grade and to other practical considerations.

It is distinctly desirable, furthermore, that these best views should appear at definite points along the road or trail, namely, at the point where the trail makes a major change of direction and of grade. The principle may be best stated by saying that the entire trail will be divided into sections or paragraphs. In each paragraph there will appear some important object of interest or outside riew. This will come at the end of the section or paragraph; and the culminating point of our transition to a new paragraph will be marked by a comparatively abrupt change of direction and change of grade. (The former is more important than the latter.) 
It is plainly desirable, further, to have the principal view appear directly in front of the traveler at the paragraphic turn, as indicated in the sketch (fig. 4).

Some trails are nsed mainly by travel in one direction only. On them the outlooks and inlooks may he studied in this one direction. But the majority of trails are ned equally coming

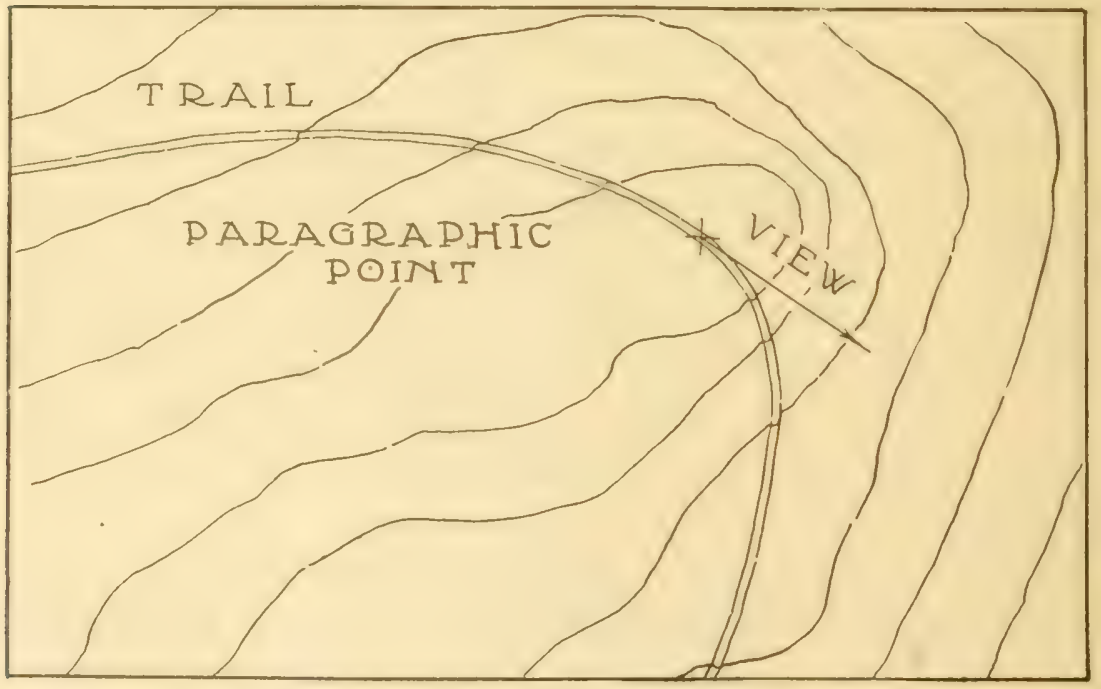

Fig. 4. -The development of trail views at paragraplic points.

and going. ()n these it is obviously necessary to study the views from both directions. Is a rule, any particular view will be risible trom one paragraphic point going out and (if shown at all) from another coming back.

As a rule, more time is taken on a trail going up; also the near-by iews are nearly always better viewed on an upgrade, while distant ontlooks shere to hest advantage from the top of a grade, 
where the traveler starts to go down. Fior these reasons the views should be studied with particular care on the upward direction of the trail, and such objects as are to be viewed closely will be especially referred to the upward ends of paragraphs.

At these paragraphic points certain things may be done to improve or emplasize the view or to call attention to it. Some of the commonest expedients are as follows: (a) To cut out the trees so as to leave a convenient opening toward the desired view, in which case the remaining trees should serve as a frame for the picture beyond; (b) to provide a widening in the road where wagons, automoliles, or trail stock may stop to rest, or to pass; (c) to place seats, especially along foot trails, where pedestrians may sit facing the best outlook; or even $(d)$ to place finger boards pointing to the riew. Such signs should usually be lettered with the name of the object pointed out, as "Peaks of Otter," "Amanoosuc River," "Mozart Falls."

One further principle will appear theoretically sound, viz, that the sucessive views in a series of paragraphs should bear a logical relation to one another, both as regards their subject matter and their order.

As nearly as possible one connected series of views should deal with one subject, theme, or motive, and one only. If one view shows a mountain peak, the next a waterfall, the third a stretch of open park, the fourth a mass of heavy timber, the fifth a dell of ferns, the sixth a lake, the seventh a ranch house, then the whole series is confusing and meaningless. It will be very much more edifying if the entire seven views in the series can show different aspects of the mountain range across the valler, or 
different views of the river along which the trail is climbing. Unity of theme or motive is the first and most fundamental principle in all art.

But the riews in such a series should also have some logical order. Certainly the best view should not come first. Perhaps it should not be quite the last, but it should be near the end. Roughly we may say that it is good management to present glimpses or partial views first, these to be synthesized later in the larger general view.

All this may sound somewhat highbrow, but anyone who notices scenery at all will enjoy the landscape better if it is effectively presented from the most farorable points in a logical series of progressive views all bearing consistently on one theme.

Such studies as these are, of course, somewhat difficult, and different degrees of artistic success may be expected in different cases and with different workers. The skill which grows from long theoretical training and the discipline of experience should certainly enable a man to do a much better piece of work than conld be done by the novice. Io doubt the forest ranger, preoceupied with timber cruising, grazing permits, or the location of fire guards, will excuse himself from any very intensive study of adranced art principles or of their application to Forest trail building. Nevertheless, most forest officers are good students and will welcome the opportunity to bring their trail-location work into line with these few fundamental principles.

At any rate there appears to be nothing unintelligible or impracticalle in the following list of points summarized from the foregoing. 


\section{in the National Forests}

I. Fior the purposes of landscape engineering each Summary trail or road should be divided into sections or paragraphs.

2. Each one of these paragraphs should present one object of interest or one important riew, these objects and riews having been selected in adrance of the trail study.

3. As far as possible the views in any series of connected paragraphs should dial with one subject, theme, or motive. When the time comes for changing to another motive the former one should be wholly dropped and undivided attention given to the new theme until it in turn is exhausted. Mixing themes is the worst possible design.

4. Each view or landscape picture should usually appear at the end of the paragraph, which should be at the point where the trail makes its principal change of direction. If a change of grade is to be made it, too, should come at this paragraphic point.

5. These hest points of view should be emphasized by appropriate means, such as cutting out trees, widening the trail, placing seats, or setting up finger boards.

6. The successive views dealing with any one theme should be presented in a progressive or climactic order. 


\section{Ranger Stations}

HE location of ranger stations on the Forests will be deter-
mined in most cases by purely practical considerations. Administrative convenience is naturally to receive first attention, and questions of this character can be settled to best advantage by the man on the ground.

Purely esthetic considerations, however, nearly always have some weight. Livery ranger desires a ranger station which has a tidy appearance and a good outlook. Nany bright examples could be found on the liorest areas of most attractive ranger stations effectively located with reference to some specially fine view and set off by neat, well-kept grounds. () the other hand it must be admitted that some mistakes have been made. ITere and there are stations quite injucliciously located, or station grounds showing distinct evidences of poor taste and bad management.

Any discussion of this matter should take into consideration the fact that the ranger station is more than an official convenience of the I'niterl States ('orernment - it is the forest ranger's home. It is entitled to the treatment which any other good citizen of the repulblic would give his home. It should have the benefit of the ringer's personal interest and the interest of his wife and fanily. 
It should be to a considerable extent the expression of the family instinct for home and of the family taste.

Leaving rcasonable latitude for these personal tastes, we need not expect to build all ranger stations on a single formula, no matter how good. Only certain broad principles may be suggested to which the house and grounds may conform with advantage to all parties.

Furthermore, if the forest ranger is to be treated like a human being, entitled to a home like other nen, he should have a reasonable anount of time when his day's work is over when he will be free to nurse his chickens, keep his garlen, mow his lawn, prune his trees, and otherwise derelop his grounds in line with his tastes and with the mild suggestions hereinafter offered. The building of a ranger station or the construction of a fence may become the official cluty of any forest officer, and may be done on official time, but the making of a home is mainly a human and unofficial enterprise and belongs to a man's hours of leisure. If, as is sometimes alleged, the forest ranger has no time for such things, then that condition requires the attention of some one besides the landscape engineer.

It is an obligation which the Government owes its employees, living as they often do under conditions of isolation and remoteness from community advantages, to see that they are decently housed and able to enjoy the things which make for a normal life. Many of the ranger headquarters are still log cabins, and the ranger's fanily is subject to the inevitable privations which confront the pioneer. The ranger himself has many and exacting duties. He must be away from home much of the time. Often 
he is away for long periods As economic development of the country in his neighborhood goes on his life will grow easier. The suggestions here made are offered as an attempt to set up a goal toward which to work as rapidly as practicable. It is felt that the ranger stations, which are the homes of these public officers and their families, should be made outposts of civilization rather than lagging survivals of the cramped and primitive conditions inposed by the wilderness.

Laying aside all questions of practical administration, and Location discussing this matter solely from the standpoint of making the surroundings more attractive, it should be clear that the ranger station should be located neither on the top of a hill nor in the bottom of a valley. In short, it will be placed somewhere on a sidehill unless the location comes in a strictly level district.

A southern exposure will usually he most desirable, though southeast or southwest may be preferable in particular cases. A northern slope is about the only one which will never be used.

When placed on a siclehill the ranger station should be set high enough to secure drainage and outlook, but not so high as to suffer from winds or he difficult of access. The location will be influenced so much by the availability of springs and similar practical necessities that any considerations of esthetic theory are likely to cut a very small figure.

It should further be clear that a situation in which the ranger station is seen against a background of trees is more desirable than one in which the forest intercepts the inlook and outlook from the front of the station. 


\section{in the National Forests}

In many parts of the country it is found desirable to fence in the grounds immediately about the ranger station. Such inclosed space will usually amount to ahout 1 acre. For this purpose a strong rustic wool fence is to be preferred. This may be of peeled posts and poles, or of rived pickets, or any other similar local material. Where sawed lumber is readily available it may be best to use sawed posts with boards. Barbed-wire fences are to be especially aroided for the yard inclosure. Any untidy, rickety construction is also obviously out of place here.

One or two gates are always necessary in such a fence. The gate offers a special opportunity for the display of good tasteor bad. It should have some interesting ornamental touch. It should not be slouchy or decrepit or unable to move on its hinges. Neither should it he fanciful nor grotesque with labored "ornamentation."

The native forest unquestionably supplies the most appro-

\section{Plantings} priate and attractive background for any ranger station. The original tree growth will be better than any planting of supposedly ornamental species. Two or three large trees within the yard or inclosure will be desirable in practically all cases. If the main trees can be placed to the south and sonthwest of the house so that their shadows help to break up the architectural lines during the day, so much the better. In all cases where trees are to be planted, select hardy native local species. Foreign, strange, or curious specimens should be let severely alone.

About the foundations of the buildings plantings of shrubbery will often prove most attractive. These should also be of native 
species. There is not a locality anywhere in any liorest where difficulty need be experienced in collecting a considerable list of ornamental shrubs. Such things as dogwood, harberry, ninebark, hawthorn, plum, viburnum, cleter, sumach, etc., are all but universal, and where these fail there are plenty of good kinds to take their places.

Much needless disappointrient is experienced in handling this native shrubbery through inproper methods in transplanting. A ranger sees some pretty slirub in full midsummer bloom along the stream, takes a fancy to it, digs it up) with his sheath-knife (losing most of the roots in the operationl, hrings it home-a three days' ride-in his saldleloags, wy which time it is thoroughly dried ont, and plants it in a dry sunny spot beside the flag pole. The thing dies, of conrse, and the ranger decides to confine himself in the future to counting sheep.

What he should do in such a case is to mark the shrub whose blossoms have awakened his adniration and make a note of the location in his notebook. Then, in late fall or early spring, when the plant is perfectly dormant, he should return to the place prepared to dig out the roots. Often the plant can be divided into several smaller winits at this operation. These smaller plants shonld be taken home and planted, never in the yard, but always in the garden nursery. That is, they should be placed in good, rich, friahle, well-cultivated soil, where they can receive the same care as corn or potatoes for one or two years. In that time and in that soil they will develop large masses of fibrous roots, so that at transplanting time they can be successfully removed to their permanent positions in the front yard or ornamental garden. 


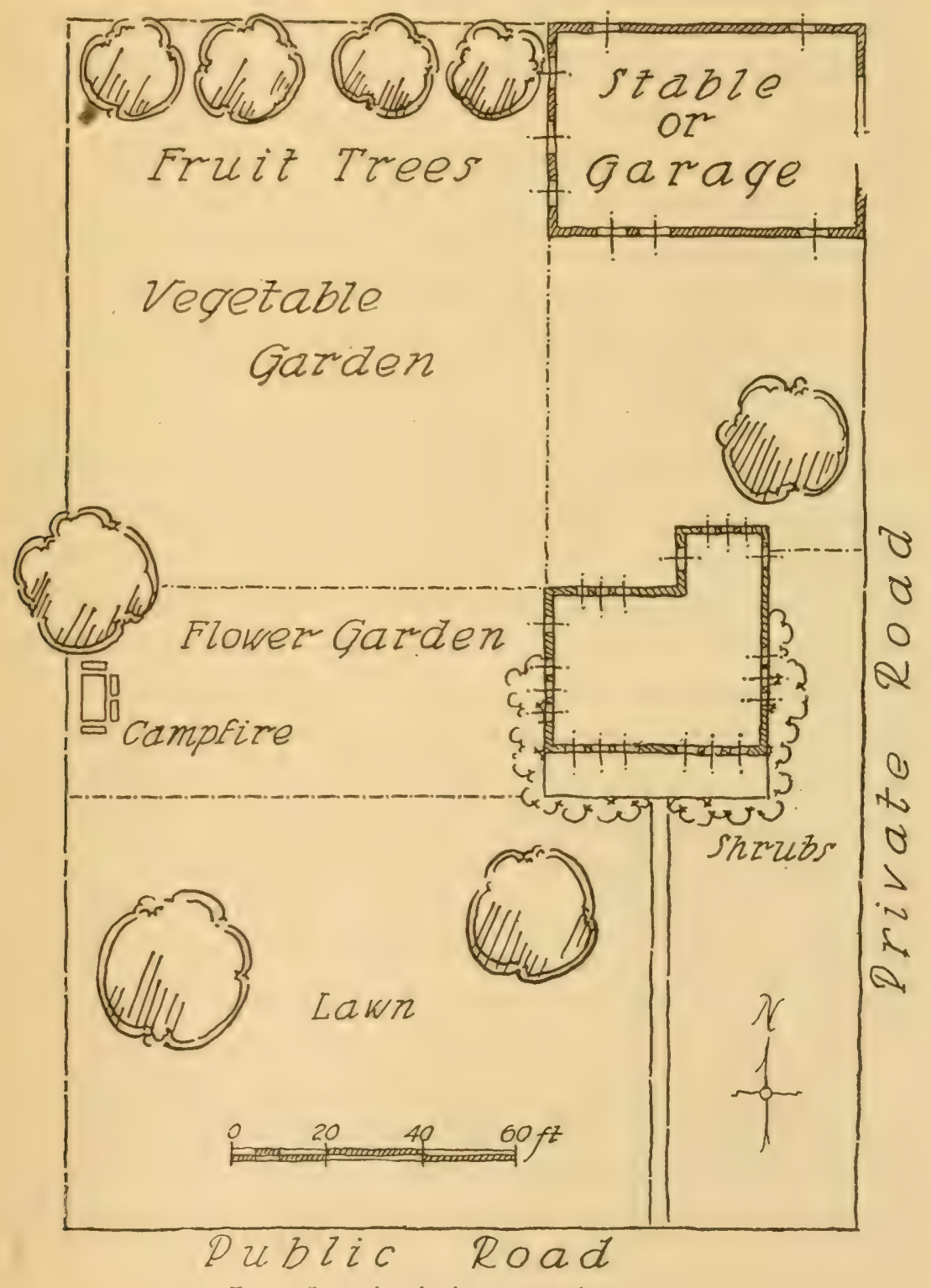

Fig. 5,-Suggestive plan for ranger station grounds. 
In these permanent positions a better effect is usually obtained by massing or grouping shrubs than by planting them singly as specimens. In planting these shrubbery masses, as for example about the house foundations, it is good practice to set the young plants rather close together, say is to $2+$ inches apart. About two or three times as many should he planted as can eventually occupy the space. Irater, as they hegin to crowd, they can be thinned out. 'This thick planting protects the young plants and gives much better results.

If the occupants of the ranger station have some taste for gardening it will be better, wherever practicable, to make a regetable garden at the back of the honse or a flower garden at the side of the house, or both, rather than to attempt to grow flowers and shruls, in the front yard. In every region there are dozens of species of hardy herbaceous flowering plants which can be easily domesticated in a cultivated flower garden if sympathetically handled. IIoreover, there is not the sliglitest objection to growing in such a garlen the old-fashioned farorites common to all circles of civilization, such as peonies, hollyhocks, tiger lilies, bleeding hearts, tulips, iris, poppies, larkspurs, phlox, etc. The point is that they will thrive much better and at the same time will look better in a cultivated garden than in a semicultivated front yard. It will be better to keep the front areas for open lawn.

For this purpose it is desirable that the land should he graded and smoothed, and, wherever it is possible with or without irrigation to grow good lawn grass, a certain area of this front yard should he well keph ihrough frequent applications of the lawn 


\section{in the National Forests}

mower. In a good many places where the lawn-mower treatment does not fit, the yard can still be mowed with a scythe from time to time with excellent effect.

The grounds about any dwelling house can nearly always Furnishings be marle more inviting by tasteful and useful furnishings. Comfortable outcloor seats are first to be considered, and with them an outdoor table will often prove a convenience. In most localities it is practicable to take meals, suppers especially, out of doors during certain parts of the year. It is a habit worthy of cultivation.

Such use of chairs and tables may raise a demand for shelter, and this demand can be met by the construction of some sort of summer house or arbor. (varden furnishings of such a character will be placed at one side or at the rear of the main house, never in front.

It is now coming to he the fashion on many of the better private grounds throughout the country to establish a camp fire as a regular item of garden equipment. This usually consists of a flat stonepared space on which the camp fire can be built, surrounded by a few rustic wooden or stone seats. Such a camp fire is delightful during the evenings of summer and autumn. Here family parties often cook and cat their suppers. Perhaps for the forest ranger the camp-fire supper will not be such a novelty; but the appropriateness of the camp fire as one of the outdoor furnishings at a ranger station should be obvious.

Bird houses at suitable points about the grounds will always prove interesting and may become the means of endless delight to the human inhabitants of the ranger station. 
In like manner fish poois can sometimes he constructed and maintained with considerable satisfaction.

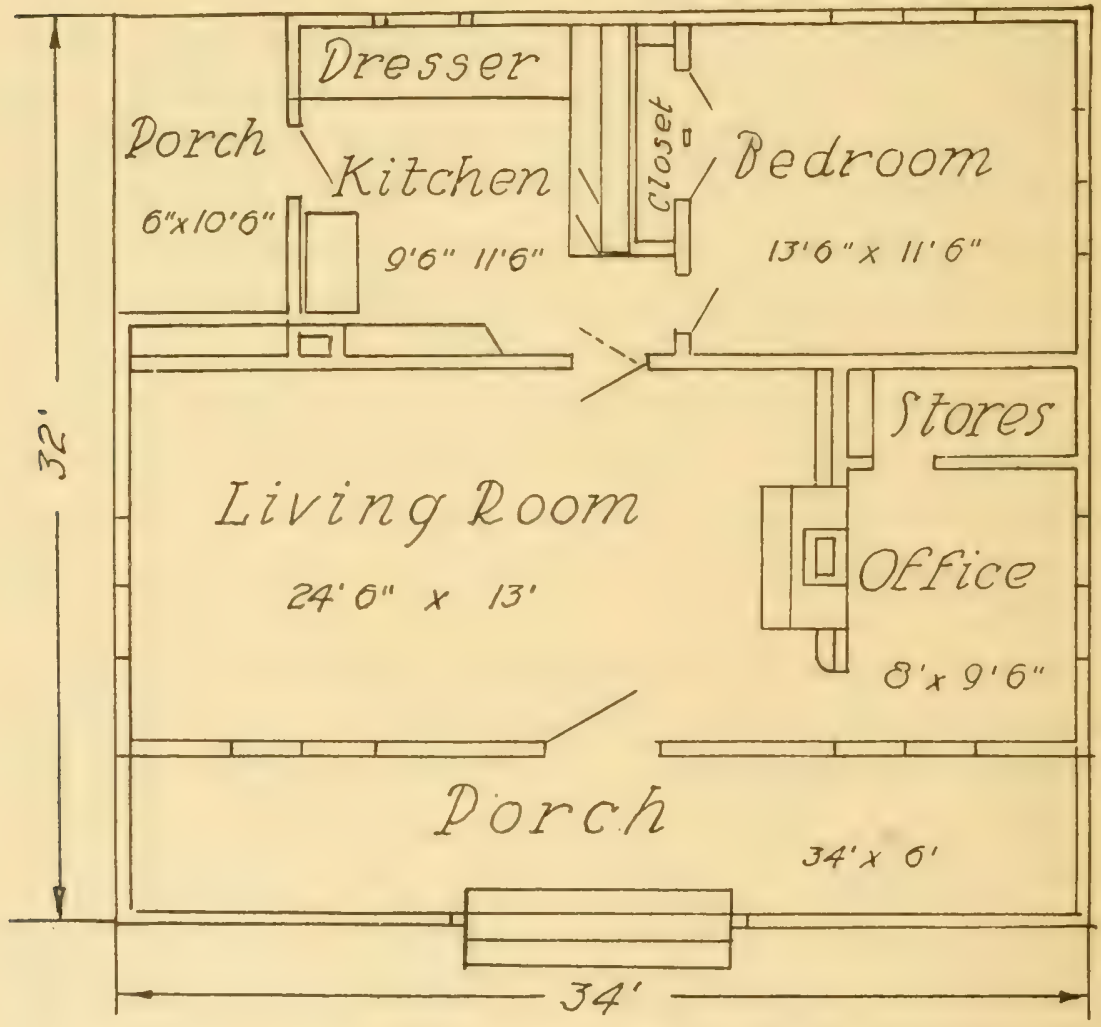

Fir. 6.-Model ranger station-Plan.

The sketch plan accompanying this discussion (fig. 5) will give a fair ilea of how these arrangements will work out into an orderly design. Such a plan, of course, will be varied to suit the circumstances. 
What has been said about the ranger station grounds applies

The Station

\section{Buildings}

in general terms to the station buildings. In some districts it has been felt that a more careful study would lead to the building of more attractive and more convenient houses and offices. Special discussion has been given to this matter in District 3 , where the feeling has

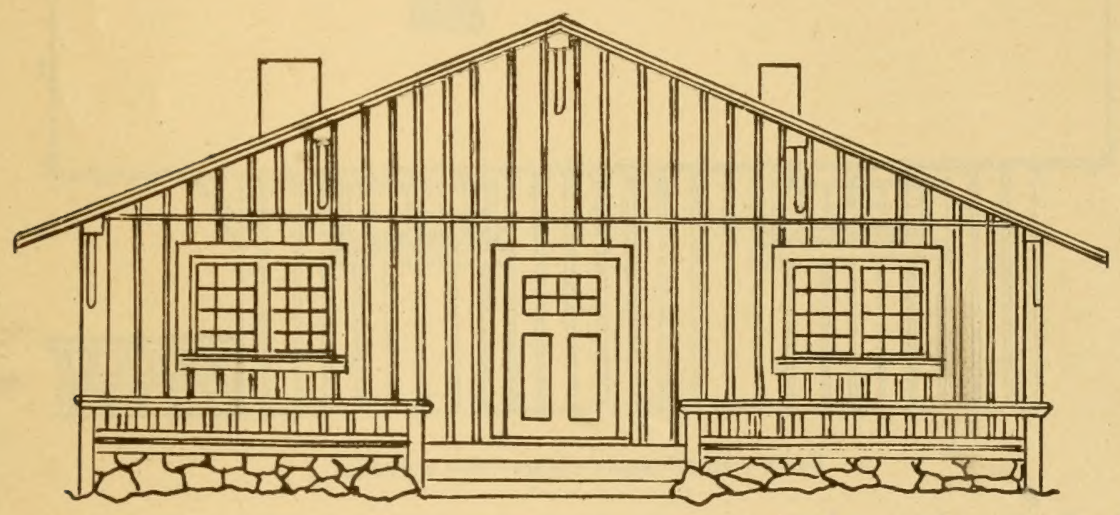

Fic, 7,-Model ranger station-Front elevation.

been strong that standardized plans and specifications might be useful. Mr. Aldo Leopold, until recently a forest examiner in this district, who has given special study to these questions, has prepared plans for such use, one of which (fig. 6), as a general suggestion, is shown herewith. 
In the judgment of the writer (and this probably expresses Mr. Leopold's view also) any strictly standardized plans, either for station buildings or grounds, are hardly feasible, owing to the great variation in the circumstances under which ranger stations must

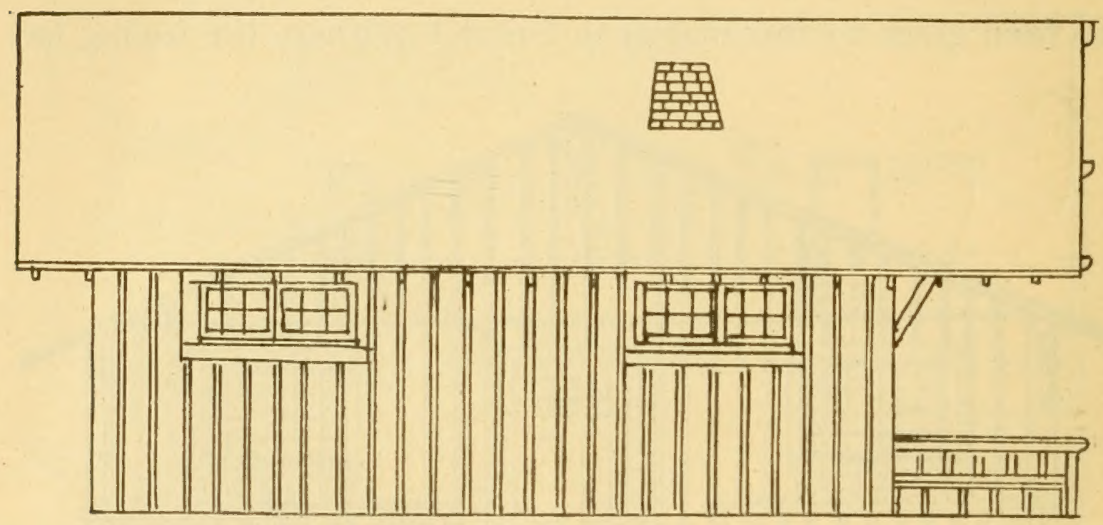

Fig. 8,-Model ranger station-Side elevation.

be built. It is clear enough, however, that much more careful study than in the past should be given to these matters. Suggestive or model plans, not to be slavishly followed, may be distinctly useful. 

LIBRARY OF CONGRESS

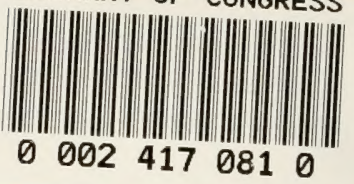

